\title{
Synthesis of $\mathrm{NiMoO}_{4}$ by the Complexation Method Combining EDTA-Citrate and its Behavior Against Biodiesel Acidity
}

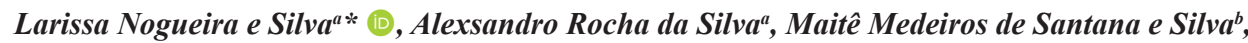 \\ Francisco Klebson Gomes dos Santos ${ }^{a}$ (D), Andarair Gomes dos Santos ${ }^{a}$ \\ ${ }^{a}$ Universidade Federal Rural do Semi-Árido - UFERSA, 59.625-900, Mossoró, RN, Brasil \\ ${ }^{b}$ Universidade Federal do Rio Grande do Norte - UFRN, 59.078-970, Natal, RN, Brasil
}

Received: September 11, 2020; Revised: March 24, 2021; Accepted: April 27, 2021

In this paper, $\mathrm{NiMoO}_{4}$ powder was synthesized by the complexation method combining EDTA-Citrate. The behavior of the $\mathrm{NiMoO}_{4}$ material in the ethyl transesterification reaction was evaluated by analyzing the acidity index under specified reaction conditions. The results showed that $\mathrm{NiMoO}_{4}$ crystallized at $800{ }^{\circ} \mathrm{C}$ with a total mass loss of $85 \%$, presenting a monoclinic structure, free of secondary phases, high degree of crystallinity and average crystallite size of $140 \mathrm{~nm}$. The particles had heterogeneous sizes and shapes, but with well-defined contours. The increase in the mass of $\mathrm{NiMoO}_{4}$ in the reaction medium reduced the acidity index $\left(0.8 \mathrm{mgKOH} . \mathrm{g}^{-1}\right.$ with $\left.15 \mathrm{wt} . \%\right)$. Despite the use of the minimum molar ratio (1:3), the ethyl route being less reactive and the use of the operating temperature close to the alcohol evaporation temperature, $\mathrm{NiMoO}_{4}$ showed promising catalytic potential in the transesterification process.

Keywords: Ethyl transesterification, temperature, reaction time, catalyst mass, acidity index.

\section{Introduction}

Transesterification, esterification, enzymatic, and ultrasound processes have been used for producing biodiesel. Among all these methods, the transesterification uses a triacylglyceride to react with an alcohol in the presence of an acid or a strong base, producing a mixture of fatty acid esters and glycerol ${ }^{1}$. The general process consists of three consecutive steps: triglycerides are converted in diglycerides and then in monoglycerides, which are later transformed into glycerol ${ }^{2}$. Due to the reversible nature of the reaction, alcohol is usually added in excess, thus favoring an increase in the yield of the ester, as well as allowing its separation from the formed glycerol ${ }^{3}$. In the transesterification and esterification processes, homogeneous, heterogeneous and, more recently, natural catalysts are usually adopted. The efficiency of heterogeneous catalysts is directly related to the nature of the sites (acidic or basic) presented according to the type of material ${ }^{4}$, which must have a high number of basic sites on the surface ${ }^{5}$ or high surface acidity ${ }^{6}$, for basic and acidic transesterification, respectively. The catalytic activity shown by solid materials that have basic Brönsted sites is linked to the interaction phenomena between the surface of the catalytic solid and the alcohol used as a transesterification agent.

For economic and mainly environmental reasons, the focus on research and development has been focused on solid catalysts in different catalytic processes, where they can be recovered and reused until their complete deactivation. Although the homogeneous process results in higher yields,

*e-mail: larissaengquimica@hotmail.com mainly free fatty acid (FFAs) content less than $1 \%$ compared to heterogeneous catalytic transesterification ${ }^{7}$, it has relevant dis-advantages in its application, such as generation of large amounts of water residuals during product separation and purification, formation of unwanted by-product by reaction of alcohol with the FFAs present in the reaction medium ${ }^{8}$ and expensive separation of the homogeneous catalyst from the reaction mixture. Homogeneous catalysts end up being diluted in biodiesel, which hinders its recovery and reuse 9 Regarding the percentage of FFAs being less than $1 \%$, they react with water in the presence of the alkaline catalyst, forming salts of fatty acids that make it difficult to separate, wash and purify biodiesel. The development of efficient heterogeneous catalysts for biodiesel production includes not only calcium ${ }^{10-12}$, magnesium, nickel, copper, strontium, and lanthanum metal oxides ${ }^{13-17}$, but also some mixed oxides ${ }^{9,18-20}$.

The structure of metal oxides is composed of positive metal ions (cations) that behave like Lewis acid (electron acceptor) and negative oxygen ions (anions) that behave as Lewis base (electron donor) ${ }^{21}$. Metal molybdates of the general formula $\mathrm{AMoO}_{4}$, where $\mathrm{A}=\mathrm{Mg}, \mathrm{Ca}, \mathrm{Zn}, \mathrm{Pb}$, among others, however, to maintain the valence balance, the cation A to the molybdenum having a +6 valence and the oxygen -2 . The molybdenum (VI)-complex has a high Lewis acidity and most certainly act on alcohol $\mathrm{O}-\mathrm{H}$ bond leading to a transient species which has high nucleophilic character ${ }^{22}$. Thus, it can be concluded that it is a very versatile material, with interesting chemical and physical properties ${ }^{23}$. Such materials are of great technological interest due to their attractive physicochemical properties. 
Nickel molybdate has been used in several applications due to its excellent properties, such as in photocatalytic reactions for degradation of organic pollutants because of its excellent performance under uv-vis light ${ }^{24}$, as catalyst in oxidative dehydrogenation reactions, which occur under specific conditions of high temperature and/or high pressure ${ }^{25-27}$, also in reactions of hydrodesulfurization and hydrodenitrogenation ${ }^{28-30}$, and more recently as a supercapacitor, as it exhibits redox pairs that act in the charging and discharging process in these devices and high specific capacitance with 94\% efficiency even after 1000 cycles according to the work of Seevakan et al. ${ }^{31}$. Saravanakumar and collaborators ${ }^{32}$ reported that it is possible to obtain nickel molybdate with different morphological configurations depending on the synthesis facings and that these influenced its performance as a capacitor. Concerning the synthesis of metal molybdates, sol-gel ${ }^{33,34}$, solvothermal ${ }^{35}$ and precipitation methods have been widely used $^{36-42}$. The complexation method combining EDTA-Citrate has stood out in recent years for synthesizingdifferent materials such as perovskites $\left(\mathrm{ABO}_{3}\right)^{29,43,44}$, fluorites $\left(\mathrm{A}_{2} \mathrm{X}_{3}\right.$, $\left.\mathrm{A}_{2} \mathrm{~B}_{2} \mathrm{X}_{7}\right)^{45,46}$, ferrites $\left(\mathrm{ABC}_{2} \mathrm{X}_{5}\right)^{47}$, and tungstates/molybdates $\left(\mathrm{AWO}_{4} / \mathrm{AMoO}_{4}\right)^{48-50}$. In general, it is a simple synthetic method that presents easy reproducibility and short synthesis time as advantages over other methods ${ }^{43,45-48}$. The possibility of manipulating synthesis parameters, such as $\mathrm{pH}$, time and calcination temperatureallows to change/modify the material properties $^{19,47,49-51}$.

To be economically viable and industrially commercialized, a catalyst must provide high conversion and long-term stability. In addition, it is extremely important to the quality of the obtained product, as physical-chemical transformations can occur due to contaminants from the raw material, production process and/or storage. Thus, the physical-chemical properties and quality analyses are of high relevance. Biodiesel production typically uses controlled amounts of phosphorus, sulfur, and carbon residue. Iodine and acidity indexes should also be monitored in the biodiesed production ${ }^{52}$. Besides, the determination of acidity is essential for obtaining high- quality biodiesel. The high acidity index hinders the reaction of biodiesel production, giving rise an acidic biodiesel that can corrode the engine and deteriorate the biofuel.

In this context, since there is no report in the literature on the preparation of $\mathrm{NiMoO}_{4}$ using the complexation method combining EDTA-Citrate, nor its use as a catalyst in the synthesis of biodiesel, it was decided to synthesize it by this method. Directing research to environmental and economic issues, the ethanol route was chosen in this work, as it has consolidated production in Brazil, being considerably less toxic than methanol ${ }^{52}$. Being the most used biodiesel production method in the Brazilian industry, transesterification uses renewable raw materials (vegetable oils and animal fats). The co-product of the process is glycerin, that can be reused in various industries (chemical, petrochemical, pharmaceutical and food). This work also reports the effect of the amount of $\mathrm{NiMoO}_{4}(1 \mathrm{wt} . \%, 5$ wot. $\%$ and $15 \mathrm{wt} . \%)$ on the biodiesel acidity index.

\section{Materials and Methods}

\subsection{Synthesis and characterization of nickel molybdate $(\mathrm{NiMoO})$ by the complexation method combining EDTA-Citrate}

$\mathrm{NiMoO}_{4}$ powders were obtained using the complexation method combining EDTA-Citrate ${ }^{44,45}$. The steps of the synthesis procedure are summarized in the flowchart shown in Figure 1. The chemicals used are shown in Table 1.

Initially, the acid EDTA was diluted in ammonium hydroxide in a ratio $1 \mathrm{~g}: 10 \mathrm{~mL}$ at $40{ }^{\circ} \mathrm{C}$ under controlled stirring (solution 1), as shown in Figure 1. Subsequently, the metal cations (solutions 2 and 3) were added. After homogeneity of the medium, citric acid (solution 4) was added to the solution and the temperature was increased to $80^{\circ} \mathrm{C}$ (solution 5), under constant stirring. The relationship between acid EDTA, citric acid and metal ions was 1:1.5:1. The $\mathrm{pH}$ was adjusted to 7 with addition of ammonium hydroxide.

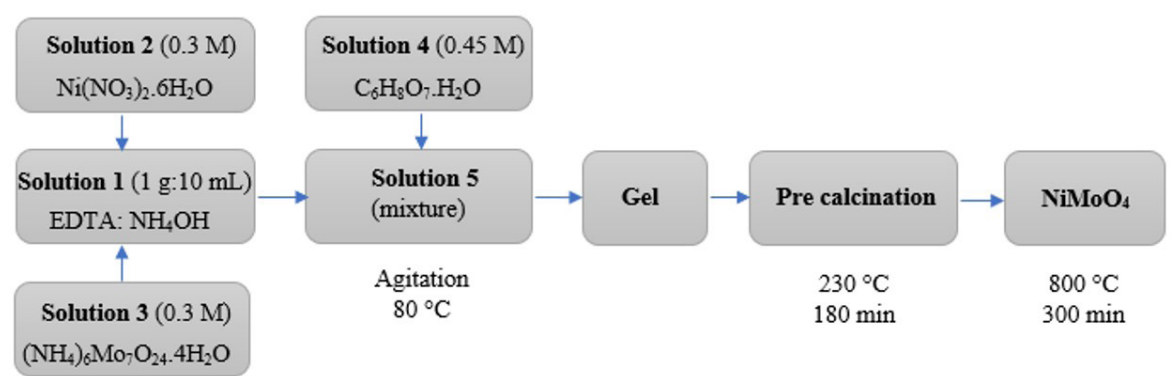

Figure 1. Flowchart of the Synthesis Methodology adopted to obtain $\mathrm{NiMoO}_{4}$.

Table 1. Chemicals used for the synthesis of $\mathrm{NiMoO}_{4}$ via the complexation method combining EDTA-Citrate.

\begin{tabular}{cccc}
\hline Reagents & Chemical formula & Purity (\%) & Manufacturer \\
\hline Citric acid & $\mathrm{C}_{6} \mathrm{H}_{8} \mathrm{O}_{7} \cdot \mathrm{H}_{2} \mathrm{O}$ & 99 & Sigma-Aldrich \\
\hline Ammonium hydroxide & $\mathrm{NH}_{4} \mathrm{OH}$ & 25 & Vetec \\
\hline Acid EDTA & $\mathrm{C}_{10} \mathrm{H}_{16} \mathrm{~N}_{2} \mathrm{O}_{8}$ & 99 & Sigma-Aldrich \\
\hline Ammonium molybdate & $\left(\mathrm{NH}_{4}\right)_{6} \mathrm{Mo}_{7} \mathrm{O}_{24} \cdot 4 \mathrm{H}_{2} \mathrm{O}$ & 99 & Sigma-Aldrich \\
\hline Nickel nitrate hexahydrate & $\left.\mathrm{Ni}_{(} \mathrm{NO}_{3}\right)_{2} \cdot 6 \mathrm{H}_{2} \mathrm{O}$ & 97 & Vetec \\
\hline
\end{tabular}


The heating and stirring of solution 5 was continued until the gel was formed. To eliminate residual water and form the organometallic compound, the resulting gel was pre-calcined at $230{ }^{\circ} \mathrm{C}$ for $180 \mathrm{~min}$ using a heating rate of $5{ }^{\circ} \mathrm{C} \cdot \mathrm{min}^{-1}$. Finally, it was calcined at $800^{\circ} \mathrm{C}$ for $300 \mathrm{~min}$.

The pre-calcined powder was investigated by thermogravimetry using the Thermal Analyzer equipment (TG/DTA Shimadzu DTG-60). The thermal analysis was carried out at the temperature range $20-900{ }^{\circ} \mathrm{C}$ (with a heating rate of $5^{\circ} \mathrm{C} \cdot \mathrm{min}^{-1}$ ) using a powder mass of $4.5 \mathrm{mg}$. The morphological assessment was performed using a Scanning Electron Microscope (SEM) with a high-sensitivity semiconductor backscattered electron detector, model Hitachi Tabletop Microscope TM-3000 (Hitachi, United States) operated with $15 \mathrm{kV}$ incident electron beam was used. The powder chemical composition was performed by X-Ray Fluorescence (XRF) in a spectrometer with EDX detector-720/800HS in a vacuum atmosphere and method of measurement by dispersive energy. Structural analysis was carried out by X-Ray Diffraction (XRD) in a Bruker D2 Phaser diffractometer, using $\mathrm{Cu}-\mathrm{K} \alpha$ radiation $(\lambda=1.5406 \AA)$ with Ni filter and Lynxeye detector in a range of $2 \theta$ from $20^{\circ}$ to $80^{\circ}$ with current $10 \mathrm{~mA}$, voltage of $30 \mathrm{kv}$ and scanning rate of $0.01 \%$. The XRD patterns were analyzed using X'pert High Score Plus 3.0e software and MAUD (Material Analysis using diffraction), version 2.84, for the Rietveld refinement analysis.

\subsection{Ethyl transesterification reaction and acidity index analysis}

The transesterification reaction was carried out using commercial soybean oil and ethyl alcohol P.A. (99.6\%) varying the catalyst mass by $1 \%, 5 \%$ and $15 \%$. $\mathrm{NiMoO}_{4}$ powder synthesized via the complexation method combining EDTACitrate obtained in neutral medium $(\mathrm{pH} 7)$ and calcined at $800{ }^{\circ} \mathrm{C}$ for $300 \mathrm{~min}$ was used as a catalyst in the reaction. The other reaction conditions for ethyl transesterification are shown in Table 2, as well as the average molar mass of soybean oil for the equation and stoichiometric relationships established according to Patzek ${ }^{53}$.

The reaction methodology of transesterification is based on Storti et al. ${ }^{18}$ and Santiago et al. ${ }^{9}$, as briefly described: initially, the oil was heated to $78^{\circ} \mathrm{C}$, then added if alcohol and after homogenization $\mathrm{NiMoO}_{4}$ was added keeping the reaction under constant stirring for $8 \mathrm{~h}$. After the reaction, $\mathrm{NiMoO}_{4}$ was separated by centrifugation $(2500 \mathrm{rpm} / 15 \mathrm{~min}$ ) and the liquid-liquid extraction was performed using $10 \%$ sodium chloride solution. Evaporation occurred at $95{ }^{\circ} \mathrm{C}$ during 15 minutes to eliminate alcohol still present. To eliminate possible residues, successive washes were carried out with distilled water at $25^{\circ} \mathrm{C}$ by measuring the $\mathrm{pH}$ of the biofuel washing water to neutral $\mathrm{pH}$.

The acidity index was determined following the official AOCS Cd 3d-63 method, as suggested by the American Oil Chemists Society (A.O.C.S.) ${ }^{54}$. The acidity index corresponds to the number of milligrams of potassium hydroxide needed to neutralize the free acidity of one gram of sample $\mathrm{e}^{55,56}$. For titration, standardized $\mathrm{NaOH}$ solutions were used on the day of analysis, using dry sodium biftalate as the primary standard ${ }^{57}$ and the previously neutralized $95 \%$ ethyl alcohol solution, according to the official method ${ }^{54}$. To minimize errors, absolute ethyl alcohol was always used, adding $5 \%$ water to obtain $95 \%$ ethyl alcohol. $25 \mathrm{~mL}$ of $95 \%$ ethyl alcohol, $0.05 \mathrm{M}$ sodium $\mathrm{NaOH}$ solution ${ }^{58}$ was used. Equation 1 was used to calculate the acidity index, where 56.1 is the molecular weight of $\mathrm{KOH}$, this value is used to convert the acidity index into milligrams of $\mathrm{KOH}$.

$I A=\frac{V \times F \times N \times 56.1}{M}$

Where:

IA: Acidity index (mgKOH.g $\left.\mathrm{g}^{-1}\right)$;

$\mathrm{V}$ : Spent volume of $\mathrm{NaOH}$ solution in the titration $(\mathrm{mL})$;

$\mathrm{F}$ : Correction factor of $\mathrm{NaOH}$ solution;

$\mathrm{N}$ : Normality of $\mathrm{NaOH}$ solution $(\mathrm{mol} / \mathrm{L})$;

M: mass of oil sample (g).

\section{Results and Discussion}

\subsection{Synthesis and characterization of nickel molybdate obtained by the complexation method combining EDTA-Citrate}

Figures 2 and 3 show the curves of Thermogravimetric Thermal Analysis (TG) and Derivative Thermogravimetry (DTG), and the refined XRD pattern of the $\mathrm{NiMoO}_{4}$ powder

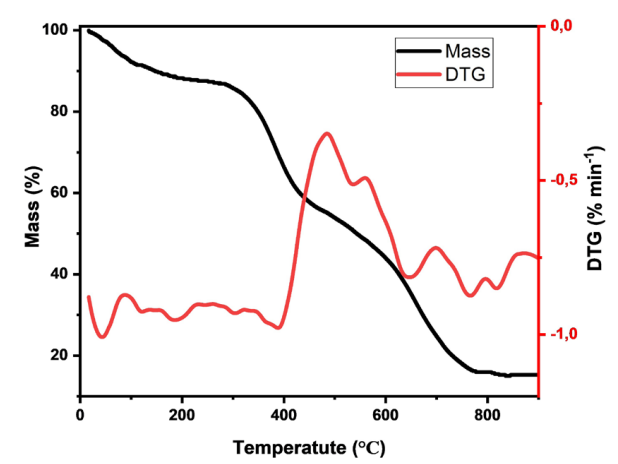

Figure 2. Thermogravimetry and Derivative Thermogravimetry (TG/DTG) of $\mathrm{NiMoO}_{4}$ synthesized via the complexation method combining EDTA-Citrate.

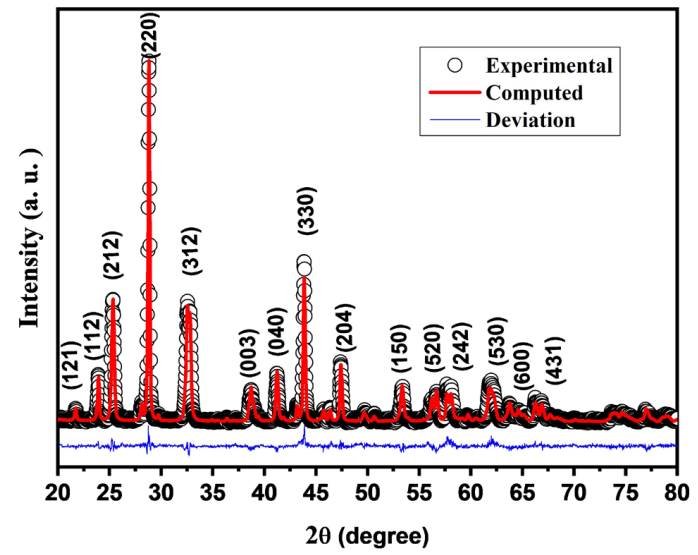

Figure 3. Refined XRD pattern of the $\mathrm{NiMoO}_{4}$ powder calcined at $800{ }^{\circ} \mathrm{C}$. 
synthesized by the complexation method combining EDTACitrate at $\mathrm{pH} 7$ and further calcined at $800{ }^{\circ} \mathrm{C}$.

In Figure 2, the solid black lines correspond to the sample mass loss (TG) and the red one is the first derivative of the mass loss curve (DTG). The first stage of mass loss of the organometallic complex occurs up to around $150{ }^{\circ} \mathrm{C}$ $(9.9 \%)$, a stage corresponding to the evaporation of water still present in the amorphous powder. Between $150^{\circ} \mathrm{C}$ and $350{ }^{\circ} \mathrm{C}$ it is estimated the elimination of residual ammonia in the organic matrix, with a mass loss of $9.9 \%$. Then, there is the decomposition of the metal chelates and pyrolysis of metals, nitrates, citrate, and EDTA corresponding to a total mass loss of $65.2 \%$, evidenced by the peak of the DTG curve, which is the organic matrix that houses the still amorphous metal elements and separated ${ }^{51}$. The $\mathrm{NiMoO}_{4}$ crystallization begins at $800{ }^{\circ} \mathrm{C}$. The nickel molybdate precursor obtained by the EDTA-Citrate methodology decomposes with temperature variation resulting in a total mass loss of $85 \%$. This loss of mass is explained by the synthetic route herein used, which uses starting reagents that undergo complete combustion during the calcination process, eliminating all organic components. The synthetic approach used in this

Table 2. Reaction conditions adopted in the ethyl transesterification reaction of soybean oil varying the mass of $\mathrm{NiMoO}_{4}(1,5$ and $15 \%)$.

\begin{tabular}{cc}
\hline Reaction type & Transesterification \\
\hline Route & Ethyl \\
\hline Molar mass oil & 920 g.mol \\
\hline Molar mass Ethanol & 46.07 g.mol $^{-1}$ \\
\hline Molar ratio (oil:alcohol) & $1: 3$ \\
\hline Ethanol Volume & $7 \mathrm{~mL}$ \\
\hline Oil Volume & $50 \mathrm{~mL}$ \\
\hline Stirring speed & $300 \mathrm{rpm}$ \\
\hline Reaction temperature & $78^{\circ} \mathrm{C}$ \\
\hline Reaction time & $8 \mathrm{~h}$ \\
\hline
\end{tabular}

Table 3. Structural parameters and crystallite size of $\mathrm{NiMoO}_{4}$ obtained through the Rietveld refinement.

\begin{tabular}{lccc}
\hline \multicolumn{2}{l}{$\begin{array}{l}\text { Crystalline } \\
\text { structure }\end{array}$} & \multicolumn{3}{c}{ Monoclinic } \\
\hline Space Group & \multicolumn{3}{c}{$\mathrm{C} 2 / \mathrm{m}: \mathrm{c} 1$} \\
\hline $\begin{array}{l}\text { Network } \\
\text { parameters }\end{array}$ & $\mathrm{a}(\AA)$ & $\mathrm{b}(\AA)$ & $\mathrm{c}(\AA)$ \\
\cline { 2 - 4 } & 9.588 & 8.756 & 7.663 \\
\cline { 2 - 4 } & $\alpha\left(^{\circ}\right)$ & $\beta\left(^{\circ}\right)$ & $\gamma\left({ }^{\circ}\right)$ \\
\hline $\begin{array}{lccc}\text { Cell Volume } \\
\left(\AA^{3}\right)\end{array}$ & 90 & 114.224 & 90 \\
\hline $\begin{array}{l}\text { Average } \\
\text { crystallite size } \\
(\text { nm) }\end{array}$ & & 580.9 & \\
\hline $\begin{array}{l}\text { Reliability } \\
\text { factors }\end{array}$ & $\mathrm{R}_{\text {wp }}(\%)$ & $\mathrm{R}_{\text {exp }}(\%)$ & $\mathrm{S}$ \\
\cline { 2 - 4 } & 13.20 & 12.76 & 1.035 \\
\hline
\end{tabular}

study allows to obtain high-crystallinity ceramic materials with good chemical homogeneity and free of secondary phases using a low processing time that saves energy ${ }^{48-51}$.

The XRD pattern shown in Figure 3 is characteristic of monophasic $\mathrm{NiMoO}_{4}$ with a monoclinic structure. All diffraction peaks are indexed according to the standard JCPDS card $n^{\circ}$ 00-033-0948 (Scheelite family). In the diffractogram, the presence of intense, narrow and well-defined diffraction peaks is characteristic of structurally ordered solids at long range ${ }^{37}$. It is also verified that there was a good fit between the experimental and calculated diffraction patterns. The Rietveld refinement was done using the MAUD software considering the positions of the Bragg peaks. The black dots represent the experimental points, the red line displays the data calculated from the Rietveld refinement method and the blue line (Deviation) represents the difference between the experimental data (observed) and the calculated/computed data called the residual parameter (Sig). The more linear this line is the less intense peaks the better the residual is the fit of the calculated data compared to the experimental data. The adjustment obtained by the Rietveld refinement can be confirmed by the value found for the residual parameter (Sig), which was close to the unit (Table 3). Therefore, the values obtained by Rietveld refinement are considered reliable.

The XRD data are also used to calculate structural parameters using the Rietveld refinement method $^{59}$, the results are shown in Table 3 . The values of lattice parameters for the $\mathrm{NiMoO}_{4}$ powder agree well with those presented in the JCPDS card $\mathrm{n}^{\circ} 00-033-0948(\mathrm{a}=9.5920 \AA, \mathrm{b}=8.7550 \AA$, $\mathrm{c}=7.6550 \AA$ and $\left.\beta\left({ }^{\circ}\right)=114.240\right)$. The average crystallite size obtained by the Rietveld refinement was $140 \mathrm{~nm}$, as shown in Table 3. The literature reports that crystals with lengths of $140-150 \mathrm{~nm}$ and widths from 60 to $70 \mathrm{~nm}$ can be obtained for $\mathrm{NiMoO}_{4}$ synthesized by the microemulsion method ${ }^{37}$.

Table 4 shows the chemical composition analysis of the $\mathrm{NiMoO}_{4}$ powder by Energy dispersive X-ray (EDX). It can be seen that the experimental percentage of nickel and molybdenum are close to the theoretical values. These values are tolerable, since it is an experimental study and a semi-quantitative technical analysis.

Figure 4 shows SEM images of the $\mathrm{NiMoO}_{4}$ powder.

It is possible to observe particles of heterogeneous sizes with defined contours, but with imperfect rectangular shape. Similar particles were also observed for $\mathrm{NiMoO}_{4}$ powders synthesized by the coprecipitation $\operatorname{method}^{37}$, while spherical shape are presented after calcination at $500{ }^{\circ} \mathrm{C}$ for $6 \mathrm{~h}^{55}$. This phenomenon is associated with the structural stability of the compound, which depends on the calcination temperature ${ }^{37}$. However, different morphologies are observed in the literature according to the type of synthesis method, as well as the adopted thermal treatment. Silva et al. ${ }^{60,61}$ synthesized $\mathrm{NiMoO}_{4}$ by coprecipitation $\left(1000^{\circ} \mathrm{C}\right)$ and protein sol-gel $\left(300^{\circ} \mathrm{C}\right)$ methods. They observed the formation of blocks with smooth surfaces of different sizes and shapes (powder at $1000{ }^{\circ} \mathrm{C}$ ), and the formation of small aggregates of particles (powder at $300^{\circ} \mathrm{C}$ ).

Table 4. Analysis of the chemical composition of $\mathrm{NiMoO}_{4}$ by $\mathrm{EDX}(\%)$ calcined at $800{ }^{\circ} \mathrm{C}$.

\begin{tabular}{cccc}
\hline Chemical elements & Experimental (\%) & Theoretical (\%) & Percentage error $(\%)$ \\
\hline Nickel & 44.32 & 37.96 & 14 \\
\hline Molybdenum & 55.68 & 62.04 & 10 \\
\hline
\end{tabular}


Table 5. Acidity index and reaction conditions of ethyl and methyl transesterification of soybean oil.

\begin{tabular}{|c|c|c|c|c|c|c|}
\hline Catalyst & $\begin{array}{l}\text { Catalyst } \\
\text { quantity } \\
\text { (mass \%) }\end{array}$ & $\begin{array}{l}\text { Molar ratio } \\
\text { (oil:alcohol) }\end{array}$ & Time (h) & $\begin{array}{c}\text { Temperature } \\
\left({ }^{\circ} \mathrm{C}\right)\end{array}$ & $\begin{array}{c}\text { Acidity } \\
\text { index } \\
\left(\mathrm{mgKOHg}^{-1}\right)\end{array}$ & References \\
\hline \multicolumn{7}{|c|}{ Ethyl transesterification } \\
\hline \multirow{3}{*}{$\mathrm{NiMoO}_{4}$} & 1 & \multirow{3}{*}{$1: 3$} & \multirow{3}{*}{8} & \multirow{3}{*}{78} & 1.3 & \multirow{3}{*}{ This work } \\
\hline & 5 & & & & 1.2 & \\
\hline & 15 & & & & 0.8 & \\
\hline $\mathrm{Ni}_{0,5} \mathrm{Zn}_{0,5} \mathrm{Fe}_{2} \mathrm{O}_{4}$ & 3 & $1: 15$ & 1 & 180 & 1.60 & 64 \\
\hline Amberlyst 15 Wet e Amberlyst- $26 \mathrm{OH}$ & 12.5 & $1: 150$ & 8 & 78 & 0.14 & 66 \\
\hline \multicolumn{7}{|c|}{ Methyl transesterification } \\
\hline MCM-41 impregnated with sulfated zirconia & 3 & $1: 10$ & 4 & - & 1.4 & 63 \\
\hline $\mathrm{KOH}$ & 1 & $1: 6$ & 1 & Ambient & 0.48 & 67 \\
\hline $\mathrm{H}_{2} \mathrm{SO}_{4}$ & & $1: 1$ & 1 & - & 2.1 & 65 \\
\hline
\end{tabular}

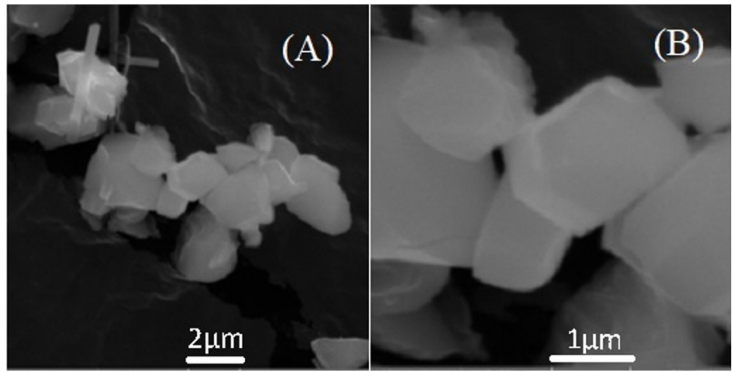

Figure 4. SEM images of the $\mathrm{NiMoO}_{4}$ powder:(A) $15 \mathrm{Kx}$ and (B) $45 \mathrm{Kx}$.

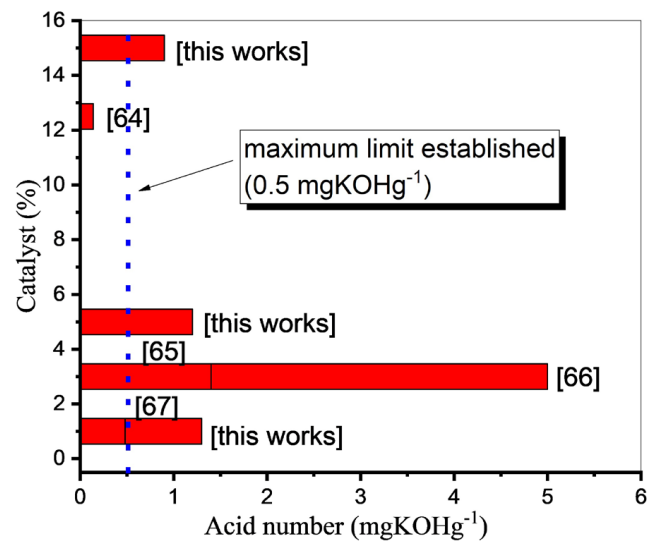

Figure 5. Behavior of the acidity index (IA) in relation to the amount of catalyst (\% by mass) in the transesterification of soybean oil.

\subsection{Catalytic test in the transesterification reaction}

Figure 5 shows the behavior of the biodiesel acidity index in relation to the percentage of catalyst in the transesterification reaction.

A decrease in the acidity index can be observed with the increase of the mass of $\mathrm{NiMoO}_{4}$ in the reaction medium keeping the molar ratio (soybean oil:ethyl alcohol) 1:3, the temperature $\left(78{ }^{\circ} \mathrm{C}\right)$ and the reaction time $(8 \mathrm{~h})$, as shown in Figure 5. When the transesterification reaction of soybean oil is catalyzed with $1 \% \mathrm{NiMoO}_{4}$ the acidity index is $1.3 \mathrm{mgKOH} . \mathrm{g}^{-1}$ and, with the increase in the amount of
$\mathrm{NiMoO}_{4}$ to $5 \%$ and $15 \%$, the acidity index reduces to 1.2 and $0.8 \mathrm{mgKOH} . \mathrm{g}^{-1}$, respectively. According to Wright et al. ${ }^{62}$, the greater the acidity, the greater the amount of catalyst needed to neutralize it. The high level of acidity still present proves the presence of high levels of fatty acids ${ }^{63}$.

Figure 5 also shows the biodiesel acidity index obtained from the ethyl and also methyl transesterification reaction when catalyzed with other distinct solid catalysts. Table 5 summarizes the studied reaction conditions of the ethyl and methyl transesterification of soybean oil to obtain biodiesel. Table 5 also includes results of the acidity index that use homogeneous catalysts, due to the limitation of the number of studies that evaluate the biodiesel acidity index.

From Table 5, the degree of complexity of the reaction process can be verified, even fixing the type of reaction (transesterification) and the source of triglycerides (vegetable oil, soybean). In addition to the different reaction parameters (temperature, time, molar ratio), the studies address different types of heterogeneous catalysts. In this universe, the emphasis in discussion is on the evaluation of the acidity index, a parameter focused on the quality of the synthesized biodiesel. According to Table 5, Pereira et al. ${ }^{63}$ and Silva et al. ${ }^{64}$, also presented high acidity indexes (1.4 and $\left.1.6 \mathrm{mgKOHg}^{-1}\right)$, in similar reaction conditions, but catalyzed with MCM-41 impregnated with zirconia and zinc doped nickel ferrite $\left(\mathrm{Ni}_{0.5} \mathrm{Zn}_{0.5} \mathrm{Fe}_{2} \mathrm{O}_{4}\right)$, respectively. Perassi et al. ${ }^{65}$ also have high indexes acidity $\left(1.88-5.35 \mathrm{mgKOHg}^{-1}\right)$, even when catalyzed with sulfuric acid. However, Oliveira et al. ${ }^{66}$ tested commercial resins (Amberlyst 15Wet and Amberlyst-26OH), where the acid number was $0.14 \mathrm{mgKOHg}^{-1}$, using the same reaction time $(8 \mathrm{~h})$ and temperature $\left(78^{\circ} \mathrm{C}\right)$ that when catalyzed with $\mathrm{NiMoO}_{4}$ (this paper), but the authors used a 1:150 molar ratio (oil:ethyl alcohol), that is, 62.5 times more ethyl alcohol in the reaction medium. On the other hand, it can also see an acid index of 0.48 with a small molar ratio (1:6) used by Morais et al. ${ }^{67}$, but $\mathrm{KOH}$ as a catalyst, as can be seen in Table 5 .

If the molar ratio adopted in the present study (1:3) is compared with the other citations, it is much smaller than the majority of the reported cases ${ }^{63,64,66,67}$, with the exception of Perassi et al. ${ }^{65}$ that catalyzed ethyl transesterification with sulfuric acid, molar ratio (1:1) (Table 5). According to 
Oliveira et al. ${ }^{66}$, the continuous generation of ethyl alcohol vapor during the transesterification reaction makes it necessary to use high oil:alcohol molar ratio much higher than the theoretical value 1:3, as shown in Equation 2. In the case of methyl transesterification, a molar ratio of $1: 15^{68}, 1: 45^{69}$, $1: 6^{70}$ can be found. The increase in the oil:alcohol molar ratio and mainly the replacement of ethanol by methanol as a transesterification agent reduces the acidity index and consequently favors the conversion, since it is a reversible reaction. In addition, methanol is a short-chain alcohol, which contributes to the increase in the reaction rate due to its greater ease in being dissolved in the reaction medium, thus becoming more reactive when compared to ethanol ${ }^{68}$. According to the literature, methyl transesterification, the molar ratio commonly used is 6:1, while for ethyl alcohol, the ratio is $9: 1$ to $12: 1^{71}$.

Triglycerides $+3 R^{\prime} \mathrm{OH} \leftrightarrow 3$ fatty monoesters (methyl or ethyl) + Glycerol

Where: Cat. - catalyst e R'OH - alcohol, usually ethanol or methanol ${ }^{52,72}$.

When the acidity index is related to the maximum acidity limit established according to Ordinance No. 255 by ANP ${ }^{73}$, European (EN 14214) and American (ASTM D6751) ${ }^{53}$, biodiesel cannot have an acidity index greater than $0.5 \mathrm{mgKOHg}^{-1}$ for commercialization. Thus, only the transesterification reactions catalyzed by $\mathrm{KOH}^{67}$ and by commercial resins ${ }^{66}, 0.48$ and $0.14 \mathrm{mgKOHg}^{-1}$, respectively, analyzed here, are within the established standards. One way to try to probably reduce the acidity index in the product formed in this case, maintaining the ethyl route and the temperature conditions and the catalyst mass would be to increase the oil:alcohol molar ratio. Another way to reduce, when you have acidic oils and/or biodiesel, would be to perform an acid pretreatment with alcohol and sulfuric acid followed by a transesterification reaction ${ }^{74,75}$, neutralization or esterification reaction ${ }^{72}$.

Based on the data shown in Figure 5 and Table 5, we can see the relevance of the analysis of the acidity index of the synthesized biodiesel. Regardless of the type of catalyst, the molar ratio oil:alcohol, the route (methyl or ethyl), as well as the reaction parameters (mass of the catalyst, time and reaction temperature) an acidic biodiesel can be obtained or outside the consumption norms established by the competent bodies, even with high conversion of oil into biodiesel, as in the papers presented by Pereira et al. ${ }^{63}$, Oliveira et al. ${ }^{66}$ and Morais et al. ${ }^{67}$. Thus, it is the most coherent even before studying the conditions of catalytic conversion, which requires an apparatus composed of the reaction system connected to an analysis system, usually chromatographic methods for the analysis of the biodiesel ${ }^{51}$. Once they are high cost techniques that require consumption of gas, energy and operational time, it would be essential to carry out analytical methods to evaluate the quality of biodiesel, as well as the raw material to be tested in the reaction. In this scenario, the $\mathrm{NiMoO}_{4}$ powder obtained in this work is a promising catalyst for the ethyl transesterification reaction.

\section{Conclusions}

The complexation method combining EDTA-Citrate proved to be efficient in obtaining a single-phase material with crystalline structure, with a mass loss of $85 \%$ and onset of crystallization at $800{ }^{\circ} \mathrm{C}$. The calcined $\mathrm{NiMoO}_{4}$ powder showed average crystallite size of $140 \mathrm{~nm}$ and irregular particle morphology. As for its chemical composition, nickel molybdate presents a tolerable percentage error, with good agreement with the theoretical values. As for its behavior in the transesterification reaction via the ethyl route, there was a significant reduction in the acidity index, even under limited reaction conditions. It is also possible to verify biodiesel with high indexes acidity, even with high degrees of conversion of soybean oil under similar reaction conditions.

\section{Acknowledgments}

The authors thank to LAMNRC/PPGEQ/UFRN, CPVSA/ UFERSA, LEMOp/UERN and Macedo, D./UFPB.

\section{References}

1. Dantas J, Leal E, Mapossa AB, Silva AS, Costa ACFM. Síntese, caracterização e performance catalítica de nanoferritas mistas submetidas a reação de transesterificação e esterificação via rota metílica e etílica para biodiesel. Materia. 2016;21(4):1080-93. http://dx.doi.org/10.1590/s1517-707620160004.0099.

2. Shuit SH, Yee KF, Lee KT, Subhash B, Tan SH. Evolution towards the utilisation of functionalised carbon nanotubes as a new generation catalyst support in biodiesel production: an overview. RSC Advances. 2013;3(24):9070. http://dx.doi. org/10.1039/c3ra22945a.

3. Geris R, Santos NAC, Amaral BA, Maia IS, Castro VD, Carvalho JRM. Biodiesel de soja: reação de transesterificação para aulas práticas de química orgânica. Quim Nova. 2007;30(5):1369-73. http://dx.doi.org/10.1590/S0100-40422007000500053.

4. Di Serio M, Tesser R, Pengmei L, Santacesaria E. Heterogeneous catalysts for biodiesel production. Energy Fuels. 2008;22(1):20717. http://dx.doi.org/10.1021/ef700250g.

5. Kim H-J, Kang B-S, Kim M-J, Park YM, Kim D-K, Lee $\mathrm{J}-\mathrm{S}$, et al. Transesterification of vegetable oil to biodiesel using heterogeneous base catalyst. Catal Today. 2004;93-95:315-20. http://dx.doi.org/10.1016/j.cattod.2004.06.007.

6. Mbaraka I. Organosulfonic acid-functionalized mesoporous silicas for the esterification of fatty acid. J Catal. 2003;219(2):329-36. http://dx.doi.org/10.1016/S0021-9517(03)00193-3.

7. Karmakar A, Karmakar S, Mukherjee S. Properties of various plants and animals feedstocks for biodiesel production. Bioresour Technol. 2010;101(19):7201-10. http://dx.doi.org/10.1016/j. biortech.2010.04.079.

8. Sharma YC, Singh B. Development of biodiesel: current scenario. Renew Sustain Energy Rev. 2009;13(6-7):1646-51. http://dx.doi.org/10.1016/j.rser.2008.08.009

9. Santiago TSA, Martins MI, Cardoso VL. Síntese de catalisador do tipo perovskita para produção de biodiesel. In: X Congresso Brasileiro de Engenharia Química; 2014; São Carlos. Anais. São Paulo: Edgard Blücher; 2014. p. 520-2.

10. Maneerung T, Kawi S, Dai Y, Wang C-H. Sustainable biodiesel production via transesterification of waste cooking oil by using $\mathrm{CaO}$ catalysts prepared from chicken manure. Energy Convers Manage. 2016;123:487-97. http://dx.doi.org/10.1016/j. enconman.2016.06.071.

11. Marinković DM, Stanković MV, Veličković AV, Avramović JM, Miladinović MR, Stamenković OO, et al. Calcium oxide as a promising heterogeneous catalyst for biodiesel production: current state and perspectives. Renew Sustain Energy Rev. 2016;56:1387-408. http://dx.doi.org/10.1016/j.rser.2015.12.007.

12. Degirmenbasi N, Coskun S, Boz N, Kalyon DM. Biodiesel synthesis from canola oil via heterogeneous catalysis using 
functionalized $\mathrm{CaO}$ nanoparticles. Fuel. 2015;153:620-7. http:// dx.doi.org/10.1016/j.fuel.2015.03.018.

13. Rahmani Vahid B, Haghighi M, Alaei S, Toghiani J. Reusability enhancement of combustion synthesized $\mathrm{MgO} / \mathrm{MgAl}_{2} \mathrm{O}_{4}$ nanocatalyst in biodiesel production by glow discharge plasma treatment. Energy Convers Manage. 2017;143:23-32. http:// dx.doi.org/10.1016/j.enconman.2017.03.075.

14. Jeon H, Kim DJ, Kim SJ, Kim JH. Synthesis of mesoporous $\mathrm{MgO}$ catalyst templated by a PDMS-PEO comb-like copolymer for biodiesel production. Fuel Process Technol. 2013;116:32531. http://dx.doi.org/10.1016/j.fuproc.2013.07.013.

15. Xu C, Liu Q. Catalytic performance and mechanism of KFloaded catalysts for biodiesel synthesis. Catal Sci Technol. 2011;1(6):1072. http://dx.doi.org/10.1039/c1cy00022e.

16. Saxena V, Sharma S, Pandey LM. Fe(III) doped ZnO nanoassembly as a potential heterogeneous nano-catalyst for the production of biodiesel. Mater Lett. 2019;237:232-5. http:// dx.doi.org/10.1016/j.matlet.2018.11.101.

17. Zhou Q, Zhang H, Chang F, Li H, Pan H, Xue W, et al. Nano $\mathrm{La}_{2} \mathrm{O}_{3}$ as a heterogeneous catalyst for biodiesel synthesis by transesterification of Jatropha curcas L. oil. J Ind Eng Chem. 2015;31:385-92. http://dx.doi.org/10.1016/j.jiec.2015.07.013.

18. Storti F, Lanfredi S, Nobre MAL. Catalytic potential of double perovskites $\mathrm{Sr}_{1-\mathrm{x}} \mathrm{K}_{\mathrm{x}} \mathrm{TiCu}_{\mathrm{x} / 2} \mathrm{O}_{3}$, where $\mathrm{x}=0.2 ; 0.3$ and 0.5 in the biodiesel preparation. In: $58^{\circ}$ Congresso Brasileiro de Cerâmica; 2014; Bento Gonçalves. Anais. São Paulo: ABCERAM; 2014.

19. Gomes A, Ricardo R, Géssika A, Dantas O, Lobato MF. Efeito do pH, Razão molar de EDTA : ácido cítrico : íons metálicos totais e do tratamento térmico na obtenção da $\mathrm{BaCeO}_{3}$ com base no método de complexação EDTA-Citrato. Rev Verde. 2014;9(4):149-62.

20. Rashtizadeh E, Farzaneh F. Transesterification of soybean oil catalyzed by $\mathrm{Sr}-\mathrm{Ti}$ mixed oxides nanocomposite. J Taiwan Inst Chem Eng. 2013;44(6):917-23. http://dx.doi.org/10.1016/j. jtice.2013.02.008.

21. Costa PPKG. Catalisadores químicos utilizados na síntese de biodiesel. Brasília: Embrapa Agroenergia. 2011. 27 p. (Documentos; 7) [cited 2020 Sep 11]. Available from: www. cnpae.embrapa.br

22. Nakagaki S, Bail A, Santos VC, Souza VHR, Vrubel H, Nunes FS, et al. Use of anhydrous sodium molybdate as an efficient heterogeneous catalyst for soybean oil methanolysis. Appl Catal A Gen. 2008;351(2):267-74. http://dx.doi.org/10.1016/j. apcata.2008.09.026.

23. Padmanathan N, Shao H, Razeeb KM. Honeycomb micro/ nano-architecture of stable $\beta-\mathrm{NiMoO}_{4}$ electrode/catalyst for sustainable energy storage and conversion devices. Int J Hydrogen Energy. 2020;45(55):30911-23. http://dx.doi.org/10.1016/j. ijhydene.2020.08.058.

24. Umapathy V, Neeraja P, Manikandan A, Ramu P. Synthesis of $\mathrm{NiMoO}_{4}$ nanoparticles by sol-gel method and their structural, morphological, optical, magnetic and photocatlytic properties. Trans Nonferrous Met Soc China. 2017;27(8):1785-93. http:// dx.doi.org/10.1016/S1003-6326(17)60201-2.

25. Madeira LM, Herrmann JM, Freire FG, Portela MF, Maldonado FJ. Electrical conductivity, basicity and catalytic activity of Cspromoted $\alpha-\mathrm{NiMoO}_{4}$ catalysts for the oxidative dehydrogenation of n-butane. Appl Catal A Gen. 1997;158(1-2):243-56. http:// dx.doi.org/10.1016/S0926-860X(96)00421-8.

26. Madeira LM, Portela MF. Mechanistic effects resulting from the cesium-doping of $\mathrm{NiMoO}_{4}$ catalyst in n-butane oxidative dehydrogenation. Appl Catal A Gen. 2005;281(1-2):179-89. http://dx.doi.org/10.1016/j.apcata.2004.11.029.

27. Mazzocchia C, Aboumrad C, Diagne C, Tempesti E, Herrmann JM, Thomas G. On the $\mathrm{NiMoO}_{4}$ oxidative dehydrogenation of propane to propene: some physical correlations with the catalytic activity. Catal Lett. 1991;10(3-4):181-91. http://dx.doi. org/10.1007/BF00772070.
28. Kaddouri A, Anouchinsky R, Mazzocchia C, Madeira L, Portela M. Oxidative dehydrogenation of ethane on the $\alpha$ and $\beta$ phases of $\mathrm{NiMoO}_{4}$. Catal Today. 1998;40(2-3):201-6. http://dx.doi. org/10.1016/S0920-5861(98)00008-X.

29. Chen M, Wu J-L, Liu Y-M, Cao Y, Guo L, He H-Y, et al. A practical grinding-assisted dry synthesis of nanocrystalline $\mathrm{NiMoO}_{4}$ polymorphs for oxidative dehydrogenation of propane. J Solid State Chem. 2011;184(12):3357-63. http://dx.doi. org/10.1016/j.jssc.2011.10.024.

30. Farin B, Swalus C, Devillers M, Gaigneaux EM. NiMoO preparation from polyampholytic hybrid precursors: benefiting of the memory effect in the oxidative dehydrogenation of propane. Catal Today. 2013;203:24-31. http://dx.doi.org/10.1016/j. cattod.2012.03.070.

31. Seevakan K, Manikandan A, Devendran P, Shameem A, Alagesan T. Microwave combustion synthesis, magneto-optical and electrochemical properties of $\mathrm{NiMoO}_{4}$ nanoparticles for supercapacitor application. Ceram Int. 2018;44(12):13879-87. http://dx.doi.org/10.1016/j.ceramint.2018.04.235.

32. Saravanakumar B, Ramachandran SP, Ravi G, Ganesh V, Sakunthala A, Yuvakkumar R. Morphology dependent electrochemical capacitor performance of $\mathrm{NiMoO}_{4}$ nanoparticles. Mater Lett. 2017;209:1-4. http://dx.doi.org/10.1016/j.matlet.2017.07.095.

33. Cauzzi D, Deltratti M, Predieri G, Tiripicchio A, Kaddouri A, Mazzocchia C, et al. Synthesis of $\mathrm{MMoO}_{4} / \mathrm{SiO}_{2}$ catalysts $(\mathrm{M}=\mathrm{Ni}$ or $\mathrm{Co})$ by a sol-gel route via silicon alkoxides. Appl Catal A Gen. 1999;182(1):125-35. http://dx.doi.org/10.1016/ S0926-860X(98)00359-7.

34. Kaddouri A, Tempesti E, Mazzocchia C. Comparative study of $\beta$-nickel molybdate phase obtained by conventional precipitation and the sol-gel method. Mater Res Bull. 2004;39(4-5):695-706. http://dx.doi.org/10.1016/j.materresbull.2003.11.005.

35. Zhang D, Zhang R, Xu C, Fan Y, Yuan B. Microwave-assisted solvothermal synthesis of nickel molybdate nanosheets as a potential catalytic platform for NADH and ethanol sensing. Sens Actuators B Chem. 2015;206:1-7. http://dx.doi.org/10.1016/j. snb.2014.09.013.

36. Eda K, Kato Y, Ohshiro Y, Sugitani T, Whittingham MS. Synthesis, crystal structure, and structural conversion of $\mathrm{Ni}$ molybdate hydrate $\mathrm{NiMoO}_{4} \cdot \mathrm{nH}_{2} \mathrm{O}$. J Solid State Chem. 2010;183(6):13349. http://dx.doi.org/10.1016/j.jssc.2010.04.009.

37. Masteri-Farahani M, Mahdavi S, Rafizadeh M. Microemulsionmediated synthesis and characterization of monodispersed nickel molybdate nanocrystals. Ceram Int. 2013;39(4):4619-25. http:// dx.doi.org/10.1016/j.ceramint.2012.11.059.

38. Kianpour G, Salavati-Niasari M, Emadi H. Precipitation synthesis and characterization of cobalt molybdates nanostructures. Superlattices Microstruct. 2013;58:120-9. http://dx.doi. org/10.1016/j.spmi.2013.01.014.

39. Shahri Z, Salavati-Niasari M, Mir N, Kianpour G. Facile synthesis and characterization of nanostructured flower-like copper molybdate by the co-precipitation method. J Cryst Growth. 2014;386:80-7. http://dx.doi.org/10.1016/j.jcrysgro.2013.09.031.

40. Zvoianu R, Dias C, Soares A, Portela M. Oxidative dehydrogenation of -butane over nanostructured silica-supported NiMoO catalysts with low content of active phase. Appl Catal A Gen. 2006;298:40-9. http://dx.doi.org/10.1016/j.apcata.2005.09.017.

41. Singh RN, Madhu, Awasthi R, Sinha ASK. Preparation and electrochemical characterization of a new $\mathrm{NiMoO}_{4}$ catalyst for electrochemical $\mathrm{O}_{2}$ evolution. J Solid State Electrochem. 2009;13(10):1613-9. http://dx.doi.org/10.1007/s10008-0080744-7.

42. Di Renzo F, Mazzocchia C. How thermal treatment influences the phase transition of $\mathrm{NiMoO}_{4}$. Thermochim Acta. 1985;85:13942. http://dx.doi.org/10.1016/0040-6031(85)85549-0.

43. Bezerra Lopes FW, Arab M, Macedo HP, Souza CP, Souza JF, Gavarri JR. High temperature conduction and methane 
conversion capability of $\mathrm{BaCeO}_{3}$ perovskite. Powder Technol. 2012;219:186-92. http://dx.doi.org/10.1016/j.powtec.2011.12.039.

44. Lobato MF, Santos AG, Vital AB, Souza CP. Síntese do cerato de bário pelo método de complexação combinando EDTA-citrato e avaliação catalítica na oxidação do monóxido de carbono testada em reator de leito fixo. Ceramica. 2016;62(363):28893. http://dx.doi.org/10.1590/0366-69132016623631993.

45. Santos A, Arab M, Patout L, de Souza C. $\mathrm{LaNi}_{03} \mathrm{Co}_{07} \mathrm{O}_{3-\delta}$ and $\mathrm{SrFe}_{0.2} \mathrm{Co}_{0.8} \mathrm{O}_{3-\delta}$ ceramic materials: structural and catalytic reactivity under CO stream. Catalysts. 2014;4(2):77-88. http:// dx.doi.org/10.3390/catal4020077.

46. Anjaneya KC, Singh MP. Synthesis and properties of gadolinium doped ceria electrolyte for IT-SOFCs by EDTA-citrate complexing method. J Alloys Compd. 2017;695:871-6. http:// dx.doi.org/10.1016/j.jallcom.2016.10.175.

47. Fernandes de Medeiros IA, Lopes-Moriyama AL, de Souza CP. Effect of synthesis parameters on the size of cobalt ferrite crystallite. Ceram Int. 2017;43(5):3962-9. http://dx.doi. org/10.1016/j.ceramint.2016.10.105.

48. Arab M, Lopes-Moriyama AL, dos Santos TR, de Souza CP, Gavarri JR, Leroux C. Strontium and cerium tungstate materials $\mathrm{SrWO}_{4}$ and $\mathrm{Ce}_{2}\left(\mathrm{WO}_{4}\right)_{3}$ : methane oxidation and mixed conduction. Catal Today. 2013;208:35-41. http://dx.doi.org/10.1016/j. cattod.2012.09.036.

49. Sena MS, Silva MMS, Santos AG, Lopes-Moriyama AL, Souza CP. Synthesis and characterization of cerium molybdate semiconductor nanoparticles. Mater Res. 2017;20(Suppl 2):48591. http://dx.doi.org/10.1590/1980-5373-mr-2017-0092.

50. Silva MMS, Sena MS, Lopes-Moriyama AL, Souza CP, Santos AG. Experimental planning of the synthesis of strontium molybdate by EDTA-citrate and its structural influence, morphology and optical bandgap. Ceram Int. 2018;44(14):16606-14. http:// dx.doi.org/10.1016/j.ceramint.2018.06.087.

51. Patra H, Rout SK, Pratihar SK, Bhattacharya S. Effect of process parameters on combined EDTA-citrate synthesis of $\mathrm{Ba}_{0.5} \mathrm{Sr}_{0.5} \mathrm{Co}_{0.8} \mathrm{Fe}_{0.2} \mathrm{O}_{3-8}$ perovskite. Powder Technol. 2011;209(13):98-104. http://dx.doi.org/10.1016/j.powtec.2011.02.015.

52. Lôbo IP, Ferreira SLC, Cruz RS. Biodiesel: parâmetros de qualidade e métodos analíticos. Quim Nova. 2009;32(6):1596608. http://dx.doi.org/10.1590/S0100-40422009000600044.

53. Patzek TW. A first law thermodynamic analysis of biodiesel production from soybean. Bull Sci Technol Soc. 2009;29(3):194204. http://dx.doi.org/10.1177/0270467609334022.

54. American Oil Chemists Society-AOCS. Official methods and recommended practices of the AOCS. Urbana, IL.

55. Freire AL, Costa BJP, Santos ZM, Pinheiro ADT. Utilização da semente do melão como catalisador na reação de esterificação do ácido oléico. In: XXI Congresso Brasileiro de Engenharia Química; 2016; Fortaleza. Anais. São Paulo: ABEQ; 2016

56. Osawa CC, Gonçalves LAG, Ragazzi S. Titulação potenciométrica aplicada na determinação de ácidos graxos livres de óleos e gorduras comestíveis. Quim Nova. 2006;29(3):593-9. http:// dx.doi.org/10.1590/S0100-40422006000300031.

57. Morita T, Assumpção RM. Manual de soluções, reagentes \& solventes: padronização, preparação, purificação. 11. ed. São Paulo: Edgard Blücher; 2011.

58. Madeley T, Postle R, Mahar T. physical properties and processing of fine Merino lamb's wool. Text Res J. 1998;68(9):663-70. http://dx.doi.org/10.1177/004051759806800907.

59. Young RA. The Rietveld method. Oxford: Oxford University Press; 1993.

60. Silva MV, Siqueira KPF. Synthesis of Nickel Molybdates: a comparative study of co-precipitation and sol-gel method. In: $41^{\mathrm{a}}$ Reunião Anual da Sociedade Brasileira de Química; 2018; Foz do Iguaçu. Anais. São Paulo: SBQ; 2018.

61. Silva MV, Oliveira DFM, Oliveira HS, Siqueira KPF. Influence of temperature on the structural and color properties of nickel molybdates. Mater Res Bull. 2020;122:110665. http://dx.doi. org/10.1016/j.materresbull.2019.110665.

62. Wright HJ, Segur JB, Clark HV, Coburn SK, Langdon EE, DuPuis RN. A report on ester interchange. Oil Soap. 1944;21(5):145-8. http://dx.doi.org/10.1007/BF02549470.

63. Pereira CE, Andrade M, Jailson J, Alves N. Catálise heterogênea para produção de biodiesel utilizando óleo refinado e de fritura. In: XX Congresso Brasileiro de Catálise; 2019; São Paulo. Anais. São Paulo: SBCat; 2019.

64. Silva AL, Farias AFF, Costa ACFM. Avaliação do tratamento térmico no catalisador magnético $\mathrm{Ni}_{0,5} \mathrm{Zn}_{0,5} \mathrm{Fe}_{2} \mathrm{O}_{4}$ e sua atividade catalítica na produção de biodiesel por transesterificação e esterificação simultânea do óleo de fritura. Ceramica. 2019;65(373):13-27. http://dx.doi.org/10.1590/0366-69132019653732408.

65. Perassi IST, Wolf MR, Assis N, Pereira FAV. Produção de biodiesel a partir de óleo de soja via rota etílica. In: Congresso Brasileiro de Engenharia Química em Iniciação Científica; 2017; São Carlos. Anais. São Paulo: Edgard Blücher; 2017. p. 1628-33. http://dx.doi.org/10.5151/chemeng-cobeqic2017-289.

66. Oliveira EVA, Costa LC, Thomaz DM, Costa MAS, Maria LCS. Transesterification of soybean oil to biodiesel by anionic and cationic ion exchange resins. Rev Virtual Química. 2015;7(6):231433. http://dx.doi.org/10.5935/1984-6835.20150138.

67. Morais VS, Castro EVR, Carneiro MTWD, Brandão GP, Fabri R Jr, Sena DR. Cor ASTM: um método simples e rápido para determinar a qualidade do biodiesel produzido a partir de óleos residuais de fritura. Quim Nova. 2013;36(4):587-92. http:// dx.doi.org/10.1590/S0100-40422013000400018.

68. Chen C-L, Huang C-C, Tran D-T, Chang J-S. Biodiesel synthesis via heterogeneous catalysis using modified strontium oxides as the catalysts. Bioresour Technol. 2012;113:8-13. http://dx.doi. org/10.1016/j.biortech.2011.12.142.

69. Mendonça IM, Paes OARL, Maia PJS, Souza MP, Almeida RA, Silva CC, et al. New heterogeneous catalyst for biodiesel production from waste tucumã peels (Astrocaryum aculeatum Meyer): parameters optimization study. Renew Energy. 2019;130:103-10. http://dx.doi.org/10.1016/j.renene.2018.06.059.

70. Pinto BF, Garcia MAS, Costa JCS, Moura CVR, Abreu WC, Moura EM. Effect of calcination temperature on the application of molybdenum trioxide acid catalyst: screening of substrates for biodiesel production. Fuel. 2019;239:290-6. http://dx.doi. org/10.1016/j.fuel.2018.11.025.

71. Sharma YC, Singh B, Upadhyay SN. Advancements in development and characterization of biodiesel: A review. Fuel. 2008;87(12):2355-73. http://dx.doi.org/10.1016/j.fuel.2008.01.014.

72. Rovere BO, Rodrigues JH, Teleken JG. Redução do índice de acidez através da neutralização e esterificação para produção de biodiesel. Brazilian J Dev. 2020;6(5):24678-86. http://dx.doi. org/10.34117/bjdv6n5-064.

73. Brasil. Portaria ANP n ${ }^{\circ} 255$ de 15/09/2003. Diário Oficial da União; Brasília; 16 set. 2003.

74. Berrios M, Siles J, Martin M, Martin A. A kinetic study of the esterification of free fatty acids (FFA) in sunflower oil. Fuel. 2007;86(15):2383-8. http://dx.doi.org/10.1016/j.fuel.2007.02.002.

75. Marchetti JM, Miguel VU, Errazu AF. Possible methods for biodiesel production. Renew Sustain Energy Rev. 2007;11(6):130011. http://dx.doi.org/10.1016/j.rser.2005.08.006. 